\title{
PENGARUH EMOTIONAL QUOTIENT (EQ) TERHADAP KREATIVITAS BERPIKIR MATEMATIKA SISWA (STUDI KASUS DI KELAS VIII SMPN 4 KOTA CIREBON)
}

\author{
Budi Manfaat, Icih Kurniasih \\ Jurusan Pendidikan Matematika, Fakultas Tarbiyah, IAIN Syekh Nurjati Cirebon, \\ Jalan Perjuangan By Pass Cirebon 451432, Indonesia
}

Telepon: (0231) 481264

Berpikir adalah proses mental seseorang yang lebih dari sekedar mengingat dan memahami. Dengan berpikir, maka kita akan menemukan pemahaman yang kita kehendaki. Proses pembelajaran yang terjadi saat ini di sekolah cenderung monoton dan hanya mengandalkan kecerdasan intelektual saja. Kecenderungan orang berpendapat bahwa Matematika itu hanya dapat diselesaikan dengan menggunakan IQ saja, padahal dalam memecahkan permasalahan matematika juga diperlukan kesabaran, ketelitian dan kestabilan emosi. Ini berarti, semakin siswa dapat mengelola emosinya dengan baik maka semakin dapat memunculkan ide-ide kreatif dalam memecahkan suatu permasalahan. Berdasarkan studi pendahuluan penulis di SMP Negeri 4 Kota Cirebon, ada beberapa siswa yang tergolong cerdas secara emosi, ia mampu memecahkan suatu permasalahan belajar dengan sesuatu yang baru. Padahal mayoritas mereka tinggal di daerah perkotaan yang rentan akan labilnya emosi. Sehingga ini adalah hal yang menjadi permasalahan dalam penelitian penulis. Penelitian ini bertujuan untuk mengetahui seberapa tinggi Emotional Quotient (EQ) siswa dalam pembelajaran matematika, seberapa tinggi kreativitas berpikir matematika siswa dalam menyelesaikan soal dan untuk mengetahui besarnya pengaruh Emotional Quotient (EQ) terhadap kreativitas berpikir matematika siswa kelas VIII. Semakin tinggi IQ seseorang, semakin penting Emotional Quotient (EQ) berperan bagi orang tersebut karena IQ tidaklah berarti tanpa disertai dengan EQ. Sehingga keduanya pun akan berfungsi secara seimbang. Pendekatan yang digunakan dalam penelitian ini adalah pendekatan kuantitatif, sedangkan metode penelitiannya menggunakan metode expostfacto. Populasi dalam penelitian ini adalah seluruh siswa kelas VIII SMPN 4 Kota Cirebon yang berjumlah 398 siswa, sedangkan pengambilan sampel menggunakan teknik purposive sampling dengan mengambil satu kelas dari sembilan kelas yaitu kelas VIII D yang berjumlah 44 siswa. Variabel dalam penelitian ini adalah Emotional Quotient dan kreativitas berpikir matematika siswa. Adapun teknik pengumpulan data menggunakan angket dan tes. Setelah data diperoleh, kemudian data dianalisis secara deskriptif dan dilakukan pengujian statistik berupa uji regresi. Setelah diadakan penelitian dan pengolahan data berdasarkan SPSS 15 for windows dan minitab, maka hasil penelitian yang diperoleh dari Emotional Quotient (EQ) siswa menunjukkan kriteria baik (64,5\%), dengan rata-rata skor angket 90,43 dan simpangan baku 15,284. Kreativitas berpikir matematika siswa memiliki persentase sebesar $72 \%$, dengan rata-rata nilai tes sebesar 71,55 dan simpangan baku 16,353. Persamaan regresi yang dihasilkan yaitu $\hat{Y}=-15,491+0,962 X$ dengan nilai koefisien determinasi yaitu sebesar 80,9\%. Hal ini dapat diartikan bahwa pengaruh Emotional Quotient (EQ) terhadap kreativitas berpikir matematika siswa sebesar 80,9\%, sedangkan sisanya19,1\% dipengaruhi oleh faktor lain selain Emotional Quotient (EQ).

Kata kunci: Emotional Quotient (EQ), Kreativitas berpikir matematika. 


\section{PENDAHULUAN}

Dalam proses pendidikan, seorang siswa dapat dikatakan berpikir kreatif apabila ia mampu menyelesaikan atau memecahkan suatu masalah dengan menciptakan sesuatu yang baru. Sehingga kekreatifan itu dapat menimbulkan rasa puas, percaya diri dan meningkatkan harga diri. Pada dasarnya untuk berpikir kreatif itu di pengaruhi oleh faktor kecerdasan, fisik, kejiwaan maupun kondisi sosial siswa. mengingat pentingnya matematika dalam kehidupan manusia, maka bidang studi matematika ini diajarkan di sekolah mulai dari tingkat Sekolah Dasar (SD) hingga Perguruan Tinggi (PT). Dalam belajar matematika diperlukan pikiran yang tenang, sedikit santai tapi serius dan semangat. Salah satunya siswa harus memanage emosinya sehingga dalam keadaan stabil. Berdasarkan pengamatan penulis dan informasi dari guru matematika di SMPN 4 Kota Cirebon, dalam proses pembelajaran matematika itu terdapat banyak faktor yang mempengaruhi siswa untuk menciptakan kreativitas. Diantaranya adalah faktor psikologis yang mencakup kepercayaan diri, pengendalian diri, kesadaran emosi, adaptasi, optimis, inisiatif, dan motivasi. Di sisi lain, siswa-siswi SMPN 4 Kota Cirebon yang mayoritas tinggal di daerah perkotaan ini memiliki berbagai macam tekanan, pengaruh lingkungan sehingga rentan akan labilnya emosi.

faktor-faktor di atas merupakan bagian dari kecerdasan emosi atau Emotional Quotient (EQ). Kecerdasan emosi meliputi dua kecakapan yaitu kecakapan pribadi (intrapersonal) yang terdiri dari kesadaran diri, pengaturan diri dan motivasi seperti melayani, menjadi tuan rumah, berkomunikasi, berempati, mengajar, melatih, konseling, memotivasi dan bekerja sama. Adapun kecakapan sosial (interpersonal) yang terdiri dari empati dan keterampilan sosial seperti menetapkan tujuan, berinisiatif, mengevaluasi, merencanakan, melihat kesempatan, menilai, memahami diri dan berinstrospeksi. Kecerdasan emosional menentukan seberapa baik seseorang menggunakan keterampilannya untuk menciptakan suatu kreativitas termasuk intelektual. Emosi tidak hanya memberi kontribusi terhadap intelegensi, tetapi keseluruhan fungsi kehidupan manusia. Kecerdasan emosi ini sangat mempengaruhi kehidupan seseorang secara keseluruhan mulai dari keluarga, pekerjaan, serta interaksi terhadap lingkungan sosialnya. Oleh karena itu, kecerdasan emosional berperan penting juga pada cara seseorang berpikir dalam menyelesaikan masalah dalam kehidupan sehari-hari.

Dalam belajar matematika IQ itu sangat diperlukan, namun IQ tidak dapat berfungsi dengan baik tanpa partisipasi penghayatan emosional kreativitas berpikir yang dilakukannya. Sehingga kedua intelligence itu saling melengkapi. Keseimbangan antara IQ dan EQ merupakan kunci keberhasilan siswa dalam menciptakan kreativitas berpikir dalam belajar matematika. Mencapai kreativitas yang tinggi tidak hanya perlu mengembangkan rational intelligence, melainkan pula perlu mengembangkan emotional intelligence

Kecerdasan emosional bekerja secara sinergi terhadap keterampilan kognitif. Tanpa kecerdasan emosi, orang tidak akan bisa menggunakan kemampuan-kemampuan kognitif mereka sesuai dengan potensi yang maksimal. Kecerdasan emosi tersebut akan mempengaruhi perilaku tiap individu dalam mengatasi permasalahan yang muncul pada diri orang tersebut termasuk masalah berpikir dalam belajar matematika.

Keterbukaan terhadap emosi mampu menjadikan berfikir efektif dan meningkatkan kecerdasan emosinya, prestasi intelektualnya berkembang dan keterampilan sosialnya menajam. Hal itu dapat memandu siswa untuk mengakui dan menghargai perasaan diri sendiri dan orang lain serta menerapkan energi emosi dalam kehidupan sehari-hari. 
Kemampuan mengatur perasaan dengan baik, berempati, memotivasi diri sendiri, ketika menghadapi gejolak emosi diri sendiri dan orang lain, manusia harus memecahkan suatu masalah dengan kreatif, fleksibel dalam kondisi dan situasi yang kerap berubah. Itu semua merupakan kemampuan yang seharusnya dimiliki oleh setiap sumber daya manusia untuk dapat menciptakan kreativitas berpikir dalam memecahkan permasalahan belajar. Adapun pertanyaan penelitian sebagai berikut:

a. Seberapa tinggi tingkat Emotional Quotient (EQ) siswa kelas VIII SMPN Kota Cirebon dalam pembelajaran matematika?

b. Seberapa tinggi kreativitas berpikir matematika siswa kelas VIII SMPN 4 Kota Cirebon dalam menyelesaikan soal pada sub pokok bahasan luas dan keliling Lingkaran?

c. Seberapa besar pengaruh Emotional Qoutient (EQ) terhadap kreativitas berpikir matematika siswa kelas VIII SMPN 4 Kota Cirebon dalam menyelesaikan soal matematika?

\section{MATERI DAN METODE}

Emotional Quotient (EQ). Kecerdasan emosi adalah kemampuan untuk memahami perasaaan diri sendiri dan orang lain, kemampuan untuk memotivasi dirinya sendiri, mengelola emosi dengan baik pada diri sendiri dan berhubungan dengan oran lain. Kecerdasan emosi memiliki lima unsur, yakni kesadaran diri, pengaturan diri, motivasi, empati dan keterampilan sosial. Menurut Steven Stein dan Howard Book sebagaimana dikutip oleh Sayidah Faoziyah (2004: 17) bahwa garis pembagi utama kecakapan-kecakapan yang kita miliki terletak antara pikiran dan hati atau secara kognisi dan emosi. Sebagian kecakapan bersifat murni kognitif, seperti penalaran analisis dan keahlian teknis, sedangkan kecakapan lain merupakan perpaduan antara pikiran dan perasaaan. Inilah yang disebut kecakapan emosi atau Emotional Quotient.

Kecerdasan emosi bukan berarti memberikan kebebasan kepada perasaan untuk berkuasa (memanjakan perasaan) melainkan mengelola perasaan sedemikian sehingga terekspresikan secara tepat dan efektif, yang memungkinkan orang bekerja dengan lancar menuju tujuan yang hendak dicapai.

Reuven Baron dalam Nana Syaodih Sukmadinata (2007: 97) mendefinisikan EQ sebagai serangkaian kemampuan, kompetensi, dan kecakapan non kognitif, yang mempengaruhi kemampuan seseorang untuk mengatasi tuntutan dan tekanan lingkungan.

Syamsu Yusuf, dkk (2005: 240) menjelaskan bahwa kecerdasan emosi menentukan emosi kita untuk mempelajari keterampilan-keterampilan praktis yang didasarkan pada lima unsur yaitu kesadaran diri, pengaturan diri, motivasi, empati dan keterampilan sosial. Sedangkan Nana Syaodih Sukmadinata (2007: 98) mengatakan bahwa orang yang memiliki kecerdasan emosional yang tinggi adalah mereka yang mampu mengendalikan diri, gejolak emosi, memelihara dan memacu motivasi untuk terus berupaya dan tidak mudah menyerah, mampu mengendalikan stres, menerima kenyataan, dapat merasakan kesenangan walaupun dalam kesulitan.

Evelyn Williams English (2005: 143) menjelaskan bahwa: Kecerdasan intrapersonal adalah kemampuan untuk membentuk sebuah model diri seseorang yang akurat dan menggunakan model itu untuk digunakan secara efektif dalam kehidupan. Kecerdasan ini merupakan kemampuan untuk mengetahui diri sendiri dan mengambil tanggung jawab atas kehidupan dan proses belajar seseorang.

Kecerdasan intrapersonal juga dapat diartikan sebagai kecakapan memahami emosional, membedakan emosi orang lain, mengetahui kekuatan dan kelemahan diri, kecakapan membentuk persepsi yang tepat, merencanakan dan mengarahkannya dalam kehidupan yang lain. 
Dari beberapa pengertian diatas dapat penulis simpulkan bahwa kecerdasan emosi atau Emotional Quotient (EQ) adalah serangkaian kemampuan, kecakapan non kognitif untuk mengenali perasaan diri sendiri dan orang lain serta dapat mengendalikan perasaan tersebut dengan baik dalam mengatasi tuntutan dan tekanan lingkungan.

kreativitas berpikir matematika. Salah satu kemampuan utama yang memegang peranan penting dalam kehidupan dan perkembangan manusia adalah kreativitas. Kreativitas merupakan kemampuan yang dimiliki oleh seseorang untuk menemukan dan menciptakan sesuatu hal baru, cara-cara baru, model baru yang berguna bagi dirinya dan bagi masyarakat. Hal baru itu tidak semestinya sesuatu yang sama sekali tidak pernah ada sebelumnya, tetapi individu menemukan kombinasi baru, hubungan baru, konstruk baru yang memiliki kualitas berbeda dengan keadaan sebelumnya. Tentunya hal baru tersebut adalah sesuatu yang sifatnya inovatif.

Menurut David Campbell sebagaimana dikutip oleh Nana Syaodih Sukmadinata (2007: 104) bahwa kreativitas adalah suatu kemampuan untuk menciptakan hasil yang sifatnya baru, inovatif, belum ada sebelumnya, menarik, aneh dan berguna bagi masyarakat.

Sedangkan menurut Utami Munandar sebagaimana dikutip oleh Nana Syaodih Sukmadinata (2007: 195) memberikan rumusan tentang kreativitas, yaitu:

a) Untuk membuat kombinasi baru, berdasarkan data, informasi atau unsur yang ada. b) menemukan banyak kemungkinan jawaban terhadap suatu masalah, dimana penekanannya adalah pada kualitas, ketepatgunaan dan keragaman jawaban. c) mencerminkan kelancaran, keluwesan, dan orisinalitas dalam berpikir serta kemampuan untuk mengelaborasi suatu gagasan.

Menurut Baron sebagaimana dikutip oleh Monty P. Satiadarma dkk, (2003: 108) bahwa kreativitas adalah segala sesuatu yang diciptakan oleh seseorang sebagai hasil dari keunikan pribadinya dalam berinteraksi dengan lingkungannya.

Karakteristik pemikiran kreatif menurut Guilford (dalam Satiadarma dan Waruyu, 2003: 108) berkaitan erat dengan lima ciri yang menjadi sifat kemampuan berpikir. Ciri tersebut yaitu meliputi kelancaran (Fluency), keluwesan (flexibility), keaslian (originality), penguraian (elaboration), dan perumusan kembali (redefinition).

Kemudian karakteristik tersebut diuraikan oleh Utami Munandar (dalam Satiadarma dan Waruyu, 2003: 109).

Kelancaran (Fluency) dalam berpikir adalah memproduksi banyak gagasan, Keluwesan (Flexibility) merupakan kemampuan untuk mengajukan berbagai pendekatan atau jalan pemecahan masalah. Keaslian (Originality) adalah kemampuan untuk gagasan asli sebagai hasil pemikiran sendiri. Penguraian (elaboration) adalah kemampuan untuk menguraikan sesuatu secara terperinci. Perumusan kembali (Redefinition) merupakan kemampuan untuk mengkaji suatu persoalan melalui cara dan perspektif berbeda dengan apa yang sudah lazim.

Kreativitas atau perbuatan kreatif banyak berhubungan dengan inteligensi (Syamsu Yusuf, 2005: 246). Seorang yang kreatif pada umumnya memiliki inteligensi yang cukup tinggi. Seorang yang tingkat inteligensinya rendah, maka kreativitasnya juga cukup kurang. Kreativitas juga berkenaan dengan kepribadian. Seorang yang kreatif memiliki ciri-ciri kepribadian mandiri, bertanggung jawab, bekerja keras, motivasi tinggi, optimis, punya rasa ingin tahu yang besar, percaya diri, terbuka, memiliki toleransi dan kaya akan pemikiran. Dengan kata lain, orang kreatif cenderung berkepribadian extrovert.

Kreativitas berpikir merupakan suatu kemampuan yang sangat berarti dalam proses kehidupan manusia. Kreativitas yang dimiliki manusia pada dasarnya lahir bersama lahirnya manusia itu, sejak lahir manusia telah memperlihatkan kecenderungan mengaktualkan dirinya yang mencakup kemampuan kreatif. Meskipun demikian, menjadi kreatif itu tidak harus menunggu datangnya ilham. Artinya kreativitas berpikir yang dianugerahkan Tuhan sifatnya 
masih mentah dan harus diolah dan diasah dengan keuletan, kesabaran, ketekunan dan keberanian.

Menurut Bobbi DePorter dan Mike Hernacki (2005: 296-298) bahwa berpikir pada dasarnya sebagai proses otak kiri dan otak kanan dalam merespon dunia luar. Proses pemikiran yang dilakukan oleh otak kanan dan otak kiri dapat dikategorikan sebagai berikut:

Berpikir Vertikal: Suatu proses bergerak selangkah menuju tujuan seolah-olah sedang menaiki tangga.

Berpikir Lateral: Melihat permasalahan dari beberapa sudut pandang yang baru, seolah-olah melompat dari satu tangga ke tangga lainnya.

Berpikir Kritis: Berlatih atau memasukkan penilaian atau evaluasi yang cermat, seperti menilai kelayakan suatu gagasan atau produk.

Berpikir Analitis: Suatu proses memecahkan masalah menjadi bagian-bagian. Menguji setiap bagian untuk melihat bagaimana bagian tersebut saling cocok satu sama lain dan mengeksplorasi bagian-bagian tersebut untuk dikombinasikan dengan cara-cara baru.

Berpikir Strategis: Mengembangkan strategi khusus untuk perencanaan dan arah operasioperasi skala besar dengan melihat proyek itu dari sudut yang mungkin.

Berpikir tentang hasil: Meninjau tugas dari perspektif solusi yang dikehendaki.

Berpikir Kreatif: Efek yang terjadi ketika menyusun kembali fakta-fakta yang ada dan muncul dalam pandangan-pandangan baru tentang masalah.

penelitian ini yaitu siswa kelas XA MAAI Mertapada yang berjumlah 40 siswa.

Teknik Korelasional. Hubungan Emotional Quotient (EQ) dengan kreativitas berpikir matematika dapat digambarkan dengan diagram:

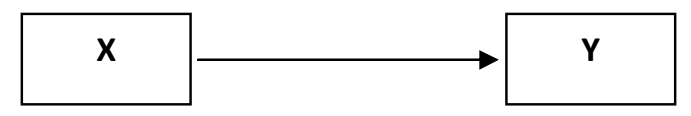

Adapun analisis data yang dilakukan adalah : Validitas, Reliabilitas, Indeks kesukaran, Daya pembeda, Uji normalitas, Uji homogenitas, Uji Kelinieran regresi dan keberartian regresi, Analisis regresi, Uji koefisien korelasi, Uji hipotesis, Koefisien Determinasi.

\section{HASIL}

\section{Deskripsi Data}

Data hasil angket Emotional Quotient. diperoleh dengan rata-rata skor angket 90,43 dan simpangan baku 15,284.

Data hasil tes kreativitas berpikir matematika. rata-rata nilai tes sebesar 71,55 dan simpangan baku 16,353.

\section{Uji Independent dan Kelinieran Regresi}

Persamaan garis regresi $\hat{Y}=-15,491+0,962 X$. Koefisien regresi sebesar 0,962 menyatakan bahwa setiap penambahan skor Emotional Quotient (EQ) sebesar satu satuan, maka akan memberikan peningkatan nilai kreativitas berpikir matematika siswa sebesar 0,962.

\section{Uji Koefisien Korelasi}

Dengan perhitungan uji koefisien korelasi diperoleh $\mathrm{r}_{\mathrm{xy}}=0,809$ yang termasuk ke dalam koefisien korelasi tinggi.

Koefisien Determinasi. koefisien determinasi sebesar 80,9\% dapat diartikan bahwa kreativitas berpikir matematika siswa di pengaruhi oleh Emotional Quotient (EQ), sisanya di tentukan oleh faktor lain. 


\section{PEMBAHASAN}

Berdasarkan hasil analisis regresi, Emotional Quotient (EQ) termasuk faktor penunjang kreativitas berpikir matematika siswa. Siswa yang dapat mengelola emosinya dengan baik cenderung mudah untuk menyesuaikan suasana belajarnya sehingga dapat menciptakan kreativitas berpikir yang baik ketika menyelesaikan soal. Sebaliknya, siswa yang tidak dapat mengelola emosinya dengan baik cenderung agak susah dalam menciptakan kreativitas berpikir matematika. Suasana emosi akan tertata dengan baik, sehingga dapat berpengaruh dalam menciptakan kreativitas berpikir siswa ketika menyelesaikan soal matematika.

Berdasarkan hasil analisis deskriptif dalam penelitian ini, secara keseluruhan Emotional Quotient (EQ) memiliki persentase sebesar 64,5\%. Dari klasifikasi skor angket, sebesar 77\% (34 siswa) tingkat EQ siswa tergolong sedang. Sedangkan sisanya, 23\% (10 siswa) tingkat EQ siswa tergolong tinggi, dan tidak ada siswa yang tergolong memiliki tingkat EQ rendah dengan jumlah keseluruhan 44 siswa.

Berdasarkan hasil penelitian, siswa SMPN 4 Kota Cirebon telah mampu menciptakan kreativitas Berpikir mereka, walaupun belum maksimal. Hal ini ditunjukkan dengan rata-rata nilai tes yang diperoleh siswa sebesar 71,55 yang menunjukkan nilai baik dengan simpangan baku sebesar 16,353. Secara keseluruhan, kreativitas berpikir matematika siswa dengan perolehan presentase sebesar $72 \%$ dapat penulis katakan bagus. Hal itu ditunjukkan oleh potensi siswa dalam menjawab soal tes kreativitas berpikir matematika siswa kepada peneliti.

Berdasarkan hasil analisis data, dapat disimpulkan bahwa Emotional Quotient (EQ) memiliki pengaruh positif terhadap kreativitas berpikir matematika siswa di SMPN 4 Kota Cirebon. Besarnya pengaruh dapat ditunjukkan dengan koefisien determinasi yaitu sebesar 80,9\% dengan persamaan garis regresi $\hat{Y}=-15,491+0,962 X$. Koefisien regresi sebesar 0,962 menyatakan bahwa setiap penambahan skor Emotional Quotient (EQ) sebesar satu satuan, maka akan memberikan peningkatan nilai kreativitas berpikir matematika siswa sebesar 0,962. Sedangkan koefisien determinasi sebesar 80,9\% dapat diartikan bahwa kreativitas berpikir matematika siswa di pengaruhi oleh Emotional Quotient (EQ), sisanya di tentukan oleh faktor lain.

Walaupun secara keseluruhan EQ siswa sebesar 64,5\% dikatakan cukup baik, namun jika di lihat dari klasifikasinya siswa yang tergolong memiliki tingkat EQ tinggi hanya 23\%. Sedangkan selebihnya tergolong pada tingkat EQ sedang. Maka dari itu, guru hendaknya mampu mendorong siswa untuk dapat mengelola emosinya dengan lebih baik. Sebagai contoh, guru memberikan motivasi kepada siswa sebelum atau ketika belajar, meyakinkan siswa bahwa belajar matematika itu tidak sulit, harus rajin dan ulet.

\section{KESIMPULAN}

Berdasarkan hasil penelitian yang telah dideskripsikan, dianalisis dan dibahas sesuai dengan ketentuan, maka penelitian yang berjudul "Pengaruh Emotional Quotient (EQ) terhadap Kreativitas Berpikir Matematika Siswa (Studi Kasus di Kelas VIII SMPN 4 Kota Cirebon) diperoleh kesimpulan sebagai berikut:

1. Emotional Quotient (EQ) secara keseluruhan dinilai baik, memiliki persentase sebesar $64,5 \%$ dari skor ideal, dengan rata-rata skor angket 90,43 dan simpangan baku 15,284. 
2. Kreativitas berpikir matematika siswa secara keseluruhan memiliki persentase sebesar $72 \%$ dari skor ideal, dengan rata-rata nilai tes sebesar 71,55 dan simpangan baku 16,353. Dengan demikian dapat disimpulkan bahwa kreativitas berpikir matematika siswa dapat dikatakan bagus.

3. Berdasarkan hasil uji regresi, diperoleh koefisien determinasi sebesar $80,9 \%$. Artinya bahwa pengaruh Emotional Quotient (EQ) terhadap kreativitas berpikir matematika siswa sebesar $80,9 \%$ dan sisanya sebesar $19,1 \%$ ditentukan oleh variabel atau faktor lain. Dengan demikian dapat disimpulkan bahwa Emotional Quotient (EQ) berpengaruh positif terhadap kreativitas berpikir matematika siswa.

Secara garis besar, penulis dapat menyimpulkan bahwa untuk dapat menciptakan kreativitas berpikir matematika yang tinggi, siswa harus mampu mengelola emosinya dengan baik ketika belajar ataupun ketika dihadapkan pada suatu permasalahan matematika. Di sisi lain, siswa juga harus mempunyai kesiapan mental dan pengetahuan.

\section{DAFTAR PUSTAKA}

Abdurrahman, Mulyono. 2003. Pendidikan Bagi Anak Berkesulitan Belajar. Jakarta: Rineka Cipta.

Al Tridhonanto. Meraih Sukses dengan Kecerdasan Emosional. Jakarta: PT Elex Media Komputindo.

Arikunto, Suharsimi. 2003. Prosedur Penelitian: Suatu Pendekatan Praktik. Jakarta: Rineka Cipta.

. . 2006. Prosedur Penelitian: Suatu Pendekatan Praktik. Jakarta: Rineka Cipta.

Djaali. 2008. Psikologi pendidikan. Jakarta: Bumi Aksara.

DePorter, Bobbi. 2010. Quantum Teaching. Bandung: Kaifa

Efendi, Agus. 2005. Revolusi Kecerdasan Abad 21. Bandung: Alfabeta.

Faoziyah, Sayidah. 2004. Pengaruh Emotional Quotient terhadap Prestasi Belajar Matematika (Studi Kasus di MTs Negeri Jalaksana Kuningan. Skripsi Matematika STAIN Cirebon. Tidak Diterbitkan.

Goleman, Daniel. 2009. Emotional Intelligence. Jakarta: PT Gramedia Pustaka Utama.

Hamalik, Oemar. 2008. Perencanaan Pengajaran Berdasarkan Pendekatan Sistem. Jakarta: Bumi Aksara.

Jauharudin. 2007. Pengaruh Peenggunaan Metode Penemuan terhadap Kemampuan Siswa dalam Menyelesaikan Soal-soal Matematika pada Pokok Bahasan Lingkaran di MTsN Karangkendal Kabupaten Cirebon. Skripsi Matematika STAIN Cirebon. Tidak Diterbitkan.

Juhairiyah. 2008. Pengaruh Emotional Quotient (EQ) dan Lingkungan Belajar terhadap Prestasi Belajar Matematika (Studi Kasus pada Siswa Kelas VIII SMP Islam Losari Brebes). Skripsi Matematika STAIN Cirebon. Tidak Diterbitkan. 
Kusmanto, Hadi. 2004. Korelasi RME dengan Kreativitas Berpikir Siswa (Upaya Menumbuhkembangkan Kreativitas Berpikir Siswa di SMPN Plumbon. Skripsi Matematika STAIN Cirebon. Tidak Diterbitkan.

Mustafa EQ, Zainal. 2009. Mengurai Variabel hingga Instrumentasi. Yogyakarta: Graha Ilmu.

Mustaqim. 2001. Psikologi Pendidikan. Yogyakarta: Pustaka Belajar.

Nasehuddien, Toto Syatori. 2008. Metodologi penelitian: Sebuah Pengantar. Cirebon: STAIN.

Nggermanto, Agus. 2003. Quantum Quotient. Bandung: Nuansa.

Priyatno, Duwi. 2010. Paham Analisis Statistik Data dengan SPSS. Jakarta: MediaKom.

R. Hoerr, Thomas. 2007. Multiple Intelligences. Bandung: Kaifa.

Riduwan. 2005. Dasar-Dasar Statistika. Bandung: Alfabeta.

_. _. _ . . 2006. Dasar-Dasar Statistika. Bandung: Alfabeta.

........ 2007. Dasar-Dasar Statistika. Bandung: Alfabeta.

Riduwan dan Akdon. 2009. Rumus dan Data dalam Analisis Statistika. Bandung: Alfabeta.

Santoso, Singgih. 2009. Business Forecasting, Metode Peramalan Bisnis Masa Kini dengan MINITAB dan SPSS. Jakarta: PT Elex Media Komputindo.

Sarwono, Jonathan. 2006. Analisis Data Menggunakan SPSS. Yogyakarta: andi.

Satiadarma, Monty P dkk. 2003. Mendidik Kecerdasan. Jakarta: Pustaka Populer Obor.

Solso, Robert dkk. 2007. Psikologi Kognitif. Jakarta: Erlangga.

Sudjana. 2005. Metode Statistika. Bandung: Tarsito.

Sugiyono. 2010. Metode Penelitian Pendidikan: Pendekatan Kuantitatif, Kualitatif, dan $R \& D$. Bandung: Alfabeta.

. . . _ _... 2007. Metode Penelitian Pendidikan: Pendekatan Kuantitatif, Kualitatif, dan $R \& D$. Bandung: Alfabeta.

_....... 2008. Metode Penelitian Pendidikan: Pendekatan Kuantitatif, Kualitatif, dan $R \& D$. Bandung: Alfabeta.

Suherman E. \& Kusumah YS. 1990. Petunjuk Untuk Menjalankan Evaluasi Matematika. Bandung: Tarsito.

Sukardi. 2008. Metodologi Penelitian Pendidikan. Jakarta: PT Bumi Aksara.

Sukmadinata, Nana Syaodih. 2007. Landasan Psikologi Proses Pendidkan. Bandung: Rosdakarya.

Sunar Prasetyo, Dwi. 2010. Super Lengkap Tes IQ-CQ. Jogjakarta: Diva Press. 
Triyana, Dewi. 2010. Pengaruh Penggunaan Metode Pemecahan Masalah Dalam Pembelajaran Matematika Terhadap Kemampuan Berpikir Kreatif Siswa (Studi Eksperimen di Kelas XI SMA Negeri 8 Kota Cirebon). Skripsi Matematika IAIN Syekh Nurjati Cirebon. Tidak Diterbitkan.

William, Evelyn. 2005. Mengajar Dengan Empati. Bandung: Nuansa.

Yusuf, Syamsu dkk. 2005. Landasan Bimbungan dan Konseling. Bandung: Rosdakarya.

http://episentrum.com//pengaruh EQ dan Kreatifitas matematika terhadap hasil belajar matematika; diunduh tanggal 05 Oktober 2010, jam 22.30 